\title{
Overcoming Antimicrobial Resistance in Bacteria Using Bioactive Magnetic Nanoparticles and Pulsed Electromagnetic Fields
}

\author{
Vitalij Novickij1*, Ramunẻ Stanevičiené2, Iglè Vepštaitè-Monstavičé2 ${ }^{2}$ Rūta Gruškiené3, \\ Tatjana Krivorotova ${ }^{4}$, Jolanta Sereikaité ${ }^{3}$, Jurij Novickij' and Elena Serviené ${ }^{2,3 *}$ \\ 1 Institute of High Magnetic Fields, Vilnius Gediminas Technical University, Vilnius, Lithuania, ${ }^{2}$ Laboratory of Genetics, \\ Institute of Botany, Nature Research Centre, Vilnius, Lithuania, ${ }^{3}$ Department of Chemistry and Bioengineering, Vilnius \\ Gediminas Technical University, Vilnius, Lithuania, ${ }^{4}$ Institute of Chemistry, Vilnius University, Vilnius, Lithuania
}

Nisin is a known bacteriocin, which exhibits a wide spectrum of antimicrobial activity, while commonly being inefficient against Gram-negative bacteria. In this work, we present a proof of concept of novel antimicrobial methodology using targeted magnetic nisin-loaded nano-carriers [iron oxide nanoparticles (NPs) (11-13 nm) capped with citric, ascorbic, and gallic acids], which are activated by high pulsed electric and electromagnetic fields allowing to overcome the nisin-resistance of bacteria. As a cell model the Gram-positive bacteria Bacillus subtilis and Gram-negative Escherichia coli were used. We have applied 10 and $30 \mathrm{kV} \mathrm{cm}^{-1}$ electric field pulses (100 $\mu \mathrm{s} \times 8$ ) separately and in combination with two pulsed magnetic field protocols: (1) high $\mathrm{dB} / \mathrm{d} t$ $3.3 \mathrm{~T} \times 50$ and (2) $10 \mathrm{mT}, 100 \mathrm{kHz}, 2$ min protocol to induce additional permeabilization and local magnetic hyperthermia. We have shown that the high $\mathrm{dB} / \mathrm{d} t$ pulsed magnetic fields increase the antimicrobial efficiency of nisin NPs similar to electroporation or magnetic hyperthermia methods and a synergistic treatment is also possible. The results of our work are promising for the development of new methods for treatment of the drug-resistant foodborne pathogens to minimize the risks of invasive infections.

Keywords: antimicrobial resistance, bacteria inactivation, B. subtilis, E. coli, iron oxide nanoparticles, nisin

\section{INTRODUCTION}

Consumption of food, which is contaminated by pathogenic bacteria represents a serious public health problem (Pinilla and Brandelli, 2016). The drug-resistant foodborne pathogens are of greatest concern due to the invasive infections, high risks of death, and massive outbreaks of disease (Roca et al., 2015; Lammie and Hughes, 2016). The situation is complicated by the increasing rates of antimicrobial resistance, which can ultimately be a consequence of the abuse or misuse of antibacterial agents (Roca et al., 2015). Therefore, the applied research of antimicrobials, alternative or combinational methods for the biocontrol, and sensitization of pathogenic microorganisms are in constant focus (Ristic et al., 2014; Ziuzina et al., 2015; Campion et al., 2017). The main interest lies within the development of natural additives and minimally processed foods to preserve taste and nutritional value (Chemat et al., 2017). Nevertheless, the array of available food preservatives, generally recognized as safe (GRAS) and approved by EU and US food and drug administration committees is limited (Gharsallaoui et al., 2016). 
One of such prominent bacteriocins (E234) unspotted in health problems is nisin, an oligopeptide produced by certain strains of Lactococcus (Cotter et al., 2012; Rao et al., 2016). Nisin is a cationic peptide composed of 34 amino acid residues. It belongs to lantibiotics and contains unusual amino acid residues dehydrobutyrine, dehydroalanine, lanthionine, and $\beta$-methyl lanthionine. The molecular mass of nisin is $3.5 \mathrm{kDa}$. However, at higher $\mathrm{pH}$ values (8-9) nisin is prone to form multimers (Gharsallaoui et al., 2016). It is active against a broad spectrum of Gram-positive foodborne pathogens; however, its use as a biopreservative is limited due to low efficiency against Gram-negative bacteria (Gharsallaoui et al., 2016; Pinilla and Brandelli, 2016). Moreover, the repeated exposure of bacteria to increasing nisin concentrations leads to patterns of nisin resistance, which also participate in the resistance to other antimicrobials or antibiotics (Blake et al., 2011; Zhou et al., 2014). Gram-negative bacteria are resistant to nisin mainly due to impermeable outer membranes, since nisin has to incorporate itself in the bacterial cell membrane by binding to essential precursors for cell wall biosynthesis, which ultimately leads to formation of pores, loss of solutes in bacteria, and subsequent cell death (Wiedemann et al., 2004; Campion et al., 2017).

The straightforward solution is to use combinational methods to improve the bacteria inactivation efficiency (i.e., garlic extracts, $\mathrm{CO}_{2}$, pressure, thermal stress), which all showed an improvement in nisin-mediated biopreservation (Lee and Kaletunç, 2010; AlHoly et al., 2012; Chandrasekaran et al., 2013; Pinilla and Brandelli, 2016; Rao et al., 2016). However, since the bacteriocins can lose their antimicrobial activity due to environmental factors such as $\mathrm{pH}$, temperature, or food composition (Zhou et al., 2014) additional encapsulation and use of nanostructures as carriers are advantageous (Lopes and Brandelli, 2017). Development of nisin-loaded nanoparticles (NPs) can improve the stability and efficiency of the nisin-mediated antimicrobial treatment (Prombutara et al., 2012; Zohri et al., 2013; Krivorotova et al., 2016). However, the physical methods that are used in combination should be targeted and preferably non-thermal to guarantee high stability and efficiency of nisin treatment, preserve nutritional value, and quality of food (Keenan et al., 2010; Rawson et al., 2011). Also, since nisin employs a plasma membrane interaction mechanism and its efficiency is highly dependent on the pore formation, the applied physical methods should be synergistic and exhibit similar effects (Novickij et al., 2016b). The perfect candidate is the pulsed electric field (PEF) processing methodology or electroporation, which triggers reversible or irreversible process of pores formation in the cell wall or cell membrane (Kotnik et al., 2012; Mahnič-Kalamiza et al., 2014; Pillet et al., 2016). The method is non-thermal and already made its way to food science and food processing as a sterilization or extraction method (Bobinaite et al., 2014; Golberg et al., 2016; Pal, 2017). However, electroporation is an emerging technique for sensitization of bacteria to antimicrobials (Khan et al., 2016; Novickij et al., 2016b; Ravensdale et al., 2016). Recently, a proof of concept that it is possible to overcome the nisin-resistance of Gram-negative bacteria using electroporation and nisin-loaded NPs was presented (Novickij et al., 2016b).
As an alternative to electroporation, a pulsed electromagnetic field (PEMF) methodology has been proposed recently (Kardos and Rabussay, 2012; Towhidi et al., 2012; Novickij et al., 2017a). The concept is based on generation of the time-varying pulsed magnetic field, which induces electric field and triggers contactless electroporation (Kranjc et al., 2016). The PEMF method has an additive effect with PEF, which allows significant increase of the treatment efficiency without contamination (Novickij et al., 2016a, 2017c). It is a fundamentally new phenomenon, which can be triggered only in extremely high magnetic fields, while the exact mechanism of the effect currently is not fully understood. However, weak PEMFbased methodologies are well studied and are frequently used in combination with magnetic NPs (Lee et al., 2011; Chandrasekaran et al., 2013; Vallejo-Fernandez et al., 2013; Niemirowicz et al., 2016). Magnetic NPs have attracted increasing attention as an efficient tool in various areas of application. In the biomedical field, they are used for magnetic hyperthermia, thermoablation therapies, targeted drug delivery, and as contrast agents for magnetic resonance imaging ( $\mathrm{Wu}$ et al., 2015). In biotechnology, iron oxide magnetic NPs functionalized with various biomolecules find their application in the biological separation, biosensing, bioremediation, and magnetofection process (Assa et al., 2016; Dinali et al., 2017).

Therefore, we have speculated that it is possible to increase the antimicrobial efficiency of nisin using different encapsulation to improve stability and binding of the structure to magnetic nanocarriers, while the nisin-resistance can be overcome by controlled poration of the cell membrane in PEF. The PEMF methodology can be further used to increase the treatment efficiency. As a result, we are first to present a proof of concept of novel antimicrobial methodology using targeted magnetic nisin nanocarriers, which are activated by combination of electric and high PEMF.

\section{MATERIALS AND METHODS}

\section{Pulsed Power Methods}

The experimental setup consisted of three generators: (1) up to $3 \mathrm{kV}, 100 \mathrm{~ns}-1 \mathrm{~ms}$ square wave high voltage pulse generator; (2) up to $3.3 \mathrm{~T}$, high $\mathrm{d} B / \mathrm{d} t$ generator, where $B$ - magnetic flux density; and (3) $10 \mathrm{mT}, 100 \mathrm{kHz}$ PEMF generation setup. The first experimental setup generated electrical pulses ( 1 and $3 \mathrm{kV}$ ) in a sequence of eight pulses $(1 \mathrm{~Hz})$ in a commercially available $1 \mathrm{~mm}$ gap electroporation cuvette (Biorad, Hercules, CA, United States). A fixed duration of $100 \mu$ s was used, which is typical in electroporation studies (Haberl Meglic et al., 2015). The resultant electric field in the cuvette was 10 and $30 \mathrm{kV} / \mathrm{cm}$, respectively.

We have used two pulsed magnetic field setups to induce different magnetic phenomena. The high $\mathrm{d} B / \mathrm{d} t$ generator was based on Marx circuit topology. The total discharge voltage was $23 \mathrm{kV}$, resulting in up to $5 \mathrm{kA}$ current in the coil (two layers, six windings), which was compatible (inner diameter of $5.2 \mathrm{~mm}$ ) with $0.2 \mathrm{ml}$ polymerase chain reaction (PCR) sterile 
tubes (Quali Electronics Inc., Columbia, SC, United States). A maximum amplitude of $3.3 \mathrm{~T}$ could be generated.

The second PEMF setup was based on the high frequency resonance oscillator with maximum current support of $70 \mathrm{~A}$. As a load $25 \mathrm{~mm}$ inner diameter coil was used (single layer, eight windings), which was compatible with standard $1.5 \mathrm{ml}$ Eppendorf tubes (Eppendorf, Hamburg, Germany). A maximum amplitude of $10 \mathrm{mT}$ could be generated at a $100 \mathrm{kHz}$ frequency. The measured waveforms of both PEMF generators and the protocols for treatment of the cells are presented in Figure 1.

The protocol EMF1 was for the high $\mathrm{d} B / \mathrm{d} t$ system and included 50 oscillations generated at repetition frequency of $0.25 \mathrm{~Hz}$ (total treatment time of $3 \mathrm{~min} 20 \mathrm{~s}$ ). High $\mathrm{d} B / \mathrm{d} t$ component allowed to induce electric field of $0.2 \mathrm{kV} \mathrm{cm}-1$ inside the sample and thus potentially enable interaction with the plasma membrane of the cell to promote permeabilization.

The protocol EMF2 was developed for the high frequency PEMF setup and was dedicated for the induction of local hyperthermia and additional motion of NPs inside the sample. The cells were subjected to $10 \mathrm{mT}, 100 \mathrm{kHz}$ PEMF for $2 \mathrm{~min}$. In both cases, the methodologies were contactless; however, the concomitant delivery of magnetic field pulses after electric field pulses was used to determine if a phenomenon of increased inactivation efficiency by PEF and PEMF can be triggered (Novickij et al., 2016a).

\section{Preparation of Nanoparticles Materials}

$\mathrm{FeSO}_{4} .7 \mathrm{H}_{2} \mathrm{O}$ ( $\geq 99 \%$ p.a.), $\alpha(+)$-ascorbic acid ( $\geq 99 \%$ p.a.) (Asc), and gallic acid (Gal) monohydrate were purchased from Roth, citric acid (Ca) monohydrate, and $\mathrm{FeCl}_{3} \cdot 6 \mathrm{H}_{2} \mathrm{O}$ were obtained from Fisher Chemicals and Merck, respectively. Nisin

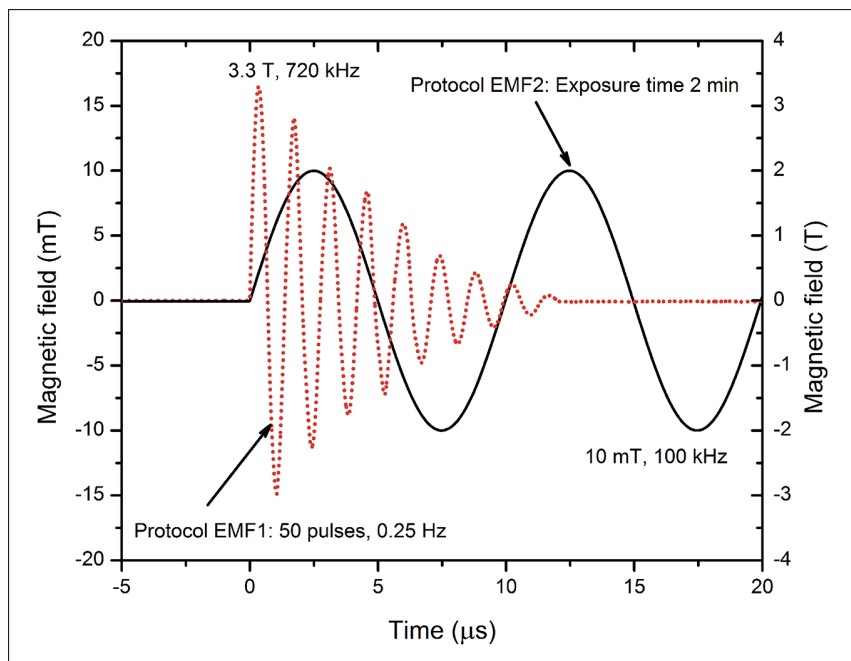

FIGURE 1 | Applied magnetic field protocols. The pulses have been measured using a calibrated loop sensor (VGTU, Vilnius, Lithuania), a DPO4034 oscilloscope (Tektronix, Beaverton, OR, United States), and a Gaussmeter 475DSP (Lakeshore, Carson, CA, United States), post-processed in OriginPro Software (OriginLab, Northampton, MA, United States).
$\left(N_{i s i n Z}{ }^{\mathrm{TM}} \mathrm{P}\right)$ was purchased from Handary S.A. (Brussels, Belgium). All materials were used without additional purification.

\section{Preparation of Nisin-Loaded Iron Oxide Magnetic Nanoparticles}

Nisin-loaded iron oxide magnetic NPs were prepared as previously described (Gruskiene et al., 2017). Briefly, under vigorous stirring, $0.587 \mathrm{~g} \mathrm{FeC}_{3} .6 \mathrm{H}_{2} \mathrm{O}$ and $0.278 \mathrm{~g} \mathrm{FeSO}_{4} .7 \mathrm{H}_{2} \mathrm{O}$ were mixed in $10 \mathrm{ml}$ of water and heated to $80^{\circ} \mathrm{C}$ under nitrogen in a three-necked flask. Then, $3.5 \mathrm{ml}$ of $\mathrm{NH}_{4} \mathrm{OH}(10 \%)$ was dropped into the solution. After reaction for $30 \mathrm{~min}$ at $80^{\circ} \mathrm{C}$, $0.3 \mathrm{~g}$ of $\mathrm{Ca}$ (Asc or Gal) in $0.6 \mathrm{ml}$ water was added directly into the reaction solution. The temperature was increased to $95^{\circ} \mathrm{C}$, and stirring continued for an additional $90 \mathrm{~min}$. Then, the solution was cooled down to room temperature naturally. The iron oxide particles were separated by a magnet from reaction mixture, washed with deionized water for several times, and dried at $45^{\circ} \mathrm{C}$ for $12 \mathrm{~h}$. The prepared dried powder was stored in the refrigerator. Before using, the required amount of iron oxide was redissolved in water using an ultrasonic water bath for $3 \mathrm{~h}$ and centrifuged at $6400 \times \mathrm{g}$ for $2 \mathrm{~h}$. The final iron oxide nanoparticles (IONP) solution was used for the following nisin loading. Synthesized iron oxide nanoparticles capped with Ca (IONP-Ca), Asc (IONP-Asc), or Gal acid (IONP-Gal) corresponded to $\mathrm{Fe}_{2} \mathrm{O}_{3}$ phase (Maghemite-C, ICDD Card No. 00-039-1346) as judged by $\mathrm{X}$-ray diffraction method.

For the preparation of nisin-loaded particles, a volume of nisin solution in water at the concentration of $10 \mu \mathrm{g} / \mathrm{ml}$ was added dropwise to the IONP solution $(0.05 \mathrm{mg} / \mathrm{ml})$ at the ratio $1 / 4(\mathrm{v} / \mathrm{v})$ under constant stirring at room temperature. For the preparation of control, instead of nisin solution, water was used. The solution of prepared nisin loaded IONP was stored at $+4^{\circ} \mathrm{C}$. Nisin loading on the particles was confirmed by Fourier transform infrared spectroscopy and thermogravimetric analysis.

The average diameter of nisin-loaded IONP-Ca, IONP-Asc, and IONP-Gal was equal to 11,13 , and $12 \mathrm{~nm}$, respectively, as determined by atomic force microscopy. Nisin-loaded NPs were stable at least for 6 weeks as judged by dynamic light scattering method. The concentration of nisin for all NPs was $2 \mu \mathrm{g} / \mathrm{ml}$.

\section{Bacterial Cultures and Growth Conditions}

Bacteria representing both Gram-positive and Gram-negative microorganisms were selected in accordance with widely adopted model organisms for laboratory studies and industrial application of PEF and food technology (Pillet et al., 2016; Murashita et al., 2017; Pan et al., 2017). Gram-negative bacteria Escherichia coli BL21 [F-dcm ompT hsdS(rB-mB-) gal $\lambda$ (DE3)] (ThermoFisher Scientific, Vilnius, Lithuania) and Gram-positive bacteria Bacillus subtilis ATCC 6633 (kindly provided by the Vilnius University, Vilnius, Lithuania) were propagated in Luria-Bertani (LB) medium ( $2 \%$ tryptone, $2 \%$ yeast extract, $1 \% \mathrm{NaCl}$ ) for $16-$ $18 \mathrm{~h}$ with continuous shaking at $37^{\circ} \mathrm{C}$. For exponential growth, overnight cultures were transferred to fresh LB medium and incubated at $37^{\circ} \mathrm{C}$ for additional $3 \mathrm{~h}$. 


\section{Analysis of Antimicrobial Activity by Agar Plate Count Method}

Stationary and exponential B. subtilis and E. coli cells $\left(1 \times 10^{7}-\right.$ $1 \times 10^{8}$ cells/sample) were collected by centrifugation at $6000 \times g$ for $5 \mathrm{~min}$, washed with $0.9 \% \mathrm{NaCl}$ solution, suspended in $100 \mu \mathrm{l}$ of solution containing nisin unloaded/loaded IONP, and used for electric and/or high PEMF treatment. Afterward samples were incubated at room temperature $\left(20^{\circ} \mathrm{C}\right)$ for $2 \mathrm{~h}$, serial dilutions performed in $0.9 \% \mathrm{NaCl}$, and $50 \mu \mathrm{l}$ of each solution was spread onto LB-agar plates with following incubation overnight at $37^{\circ} \mathrm{C}$. All assays were carried out in triplicate. After incubation, colonies were counted as colony forming units (CFU), and then the mean value of $\mathrm{CFU} / \mathrm{ml}$ was calculated.

\section{Statistical Analysis}

One-way analysis of variance (ANOVA; $P<0.05$ ) was used to compare different protocols. Tukey's HSD multiple comparison test for evaluation of the difference was used when ANOVA indicated a statistically significant result $(P<0.05$ was considered statistically significant). The data were postprocessed in OriginPro Software (OriginLab, Northampton, MA, United States). All experiments have been performed at least in triplicate and the treatment efficiency was expressed as mean \pm standard deviation normalized to untreated control sample.

\section{RESULTS}

The antimicrobial activity of NPs depends on the encapsulation method used, and therefore, we have used IONP with different capping agents. Citric and Asc are well-known stabilizers of NPs (Moore et al., 2015; Sreeja et al., 2015). Recently, Gal has been used for coating of IONP, which are applicable for trypsin immobilization by physical bonds (Atacan et al., 2016). However, these acids differ in their chemical structure and properties and consequently may influence on the chemisorption of nisin and its biological activity. Therefore, each nisin-loaded version of NPs (i.e., Nis-IONP-Ca) had a corresponding nisin-free version as a reference (IONP-Ca) to distinguish the influence of separate treatment components. The NPs have been used in combination with PEMF to induce higher inactivation efficiency.

\section{Inactivation in Pulsed Electric Fields}

The conventional protocol of $8 \times 100 \mu$ s was used with the bacteria during the exponential and the stationary growing phase. The results for E. coli are summarized in Figure 2. Both the nisin-loaded and nisin-free NPs did not result in high inactivation rates (up to $0.75 \log \mathrm{CFU}$ reduction) when used separately from electroporation. However, $30 \mathrm{kV} \mathrm{cm}^{-1}$ pulsing protocol showed a high increase in antimicrobial efficiency of the treatment (up to $3 \log$ CFU reduction).

When PEF was used separately from NPs, up to $2 \log$ reduction in cell survival was detected (Figure $2 \mathrm{~A}, 30 \mathrm{kV} \mathrm{cm}^{-1}$ ), while in all cases with the nisin-loaded NPs a synergistic treatment was triggered. The $10 \mathrm{kV} \mathrm{cm}{ }^{-1}$ PEF procedure showed a less profound effect (up to $1 \log$ reduction); however, still

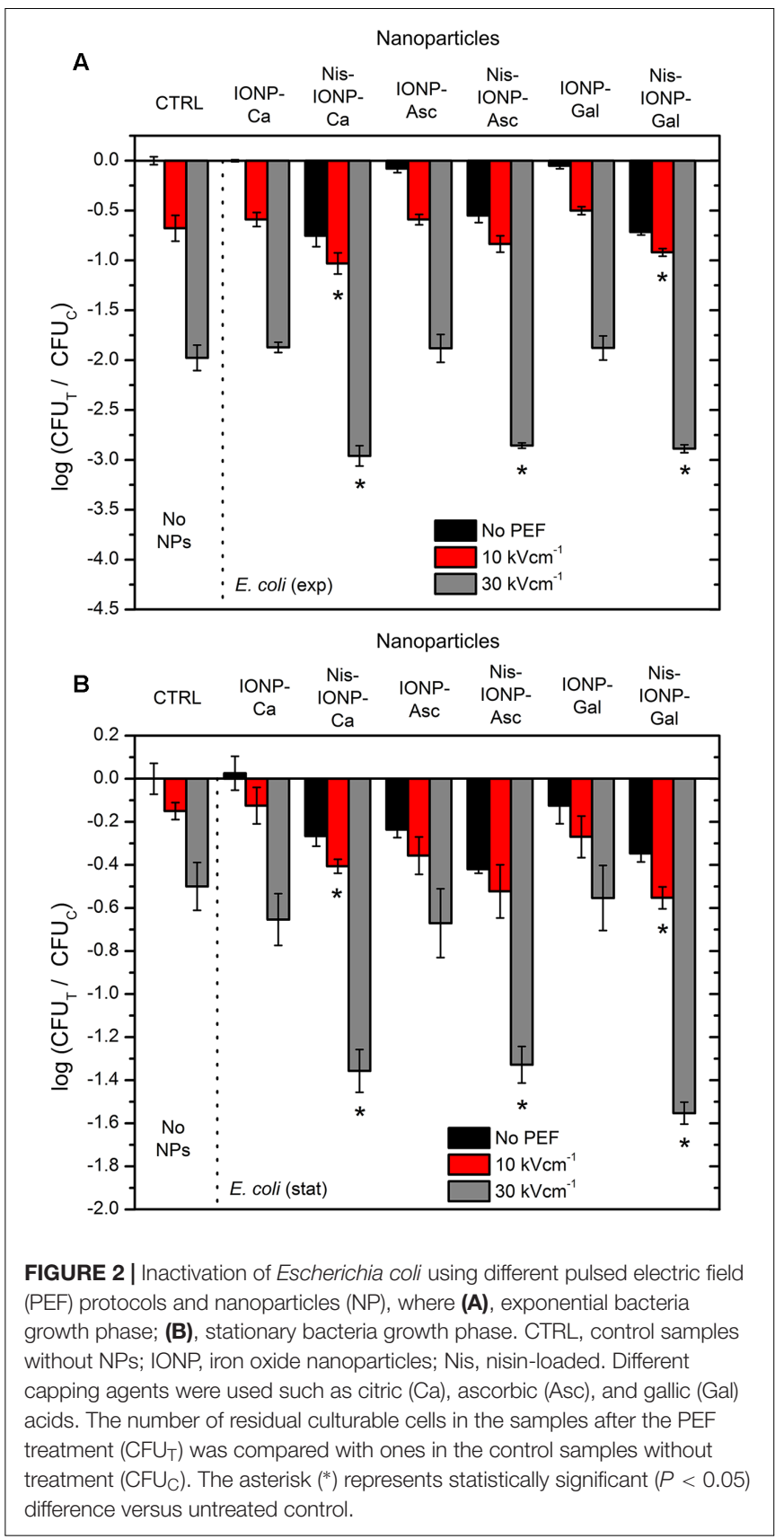

in Nis-IONP-Ca and Nis-IONP-Gal cases the difference was significant (Figure $2 \mathrm{~A}, 10 \mathrm{kV} \mathrm{cm}^{-1}$ ). The same tendency was observed for E. coli in the stationary growth phase. Bacteria were less susceptible to treatment resulting in a maximum $1.6 \log$ reduction in cell survival (PEF + NPs), nevertheless a significant improvement in inactivation efficiency was detectable if compared to separate procedures.

The same methodology was applied for Gram-positive bacteria (i.e., B. subtilis). The results are summarized in Figure 3. More than $2 \log$ reduction in cell survival was triggered solely by nisin-loaded NPs (Figure 3A, Nis-IONP-Gal). Also, the electroporation protocols were more effective, however, the 


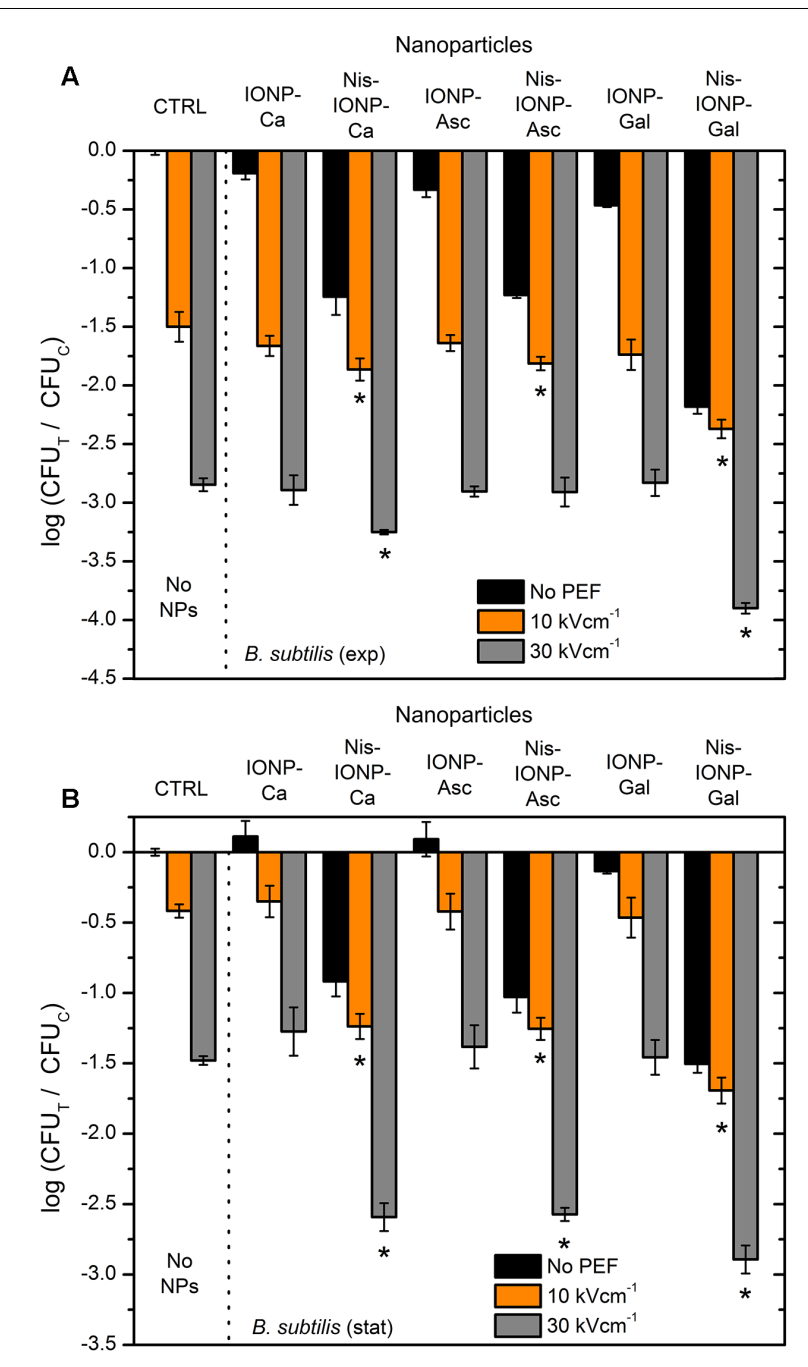

FIGURE 3 | Inactivation of Bacillus subtilis using different PEF protocols and NP, where (A), exponential bacteria growth phase; $(\mathbf{B})$, stationary bacteria growth phase. CTRL, control samples without NPs; IONP, iron oxide nanoparticles; Nis, nisin-loaded. Different capping agents were used such as $\mathrm{Ca}, \mathrm{Asc}$, and Gal acids. The number of residual culturable cells in the samples after the PEF treatment $\left(\mathrm{CFU}_{\mathrm{T}}\right)$ was compared with ones in the control samples without treatment $\left(C F U_{C}\right)$. The asterisk $\left(^{*}\right)$ represents statistically significant $(P<0.05)$ difference versus untreated control.

difference between combinational (PEF + NPs) and PEF only treatment was not as apparent as in E. coli case for most of the used NPs, which indicates a saturated permeabilization.

The results for $B$. subtilis in stationary growth phase agree with previously observed phenomena for E. coli. The synergistic treatment efficiency was detectable in all cases when nisin-loaded NPs were used in combination with PEF (Figure 3B).

\section{Inactivation in Pulsed Electromagnetic Fields}

Firstly, we have investigated the influence of EMF protocols (with and without PEF component) in distilled water. The

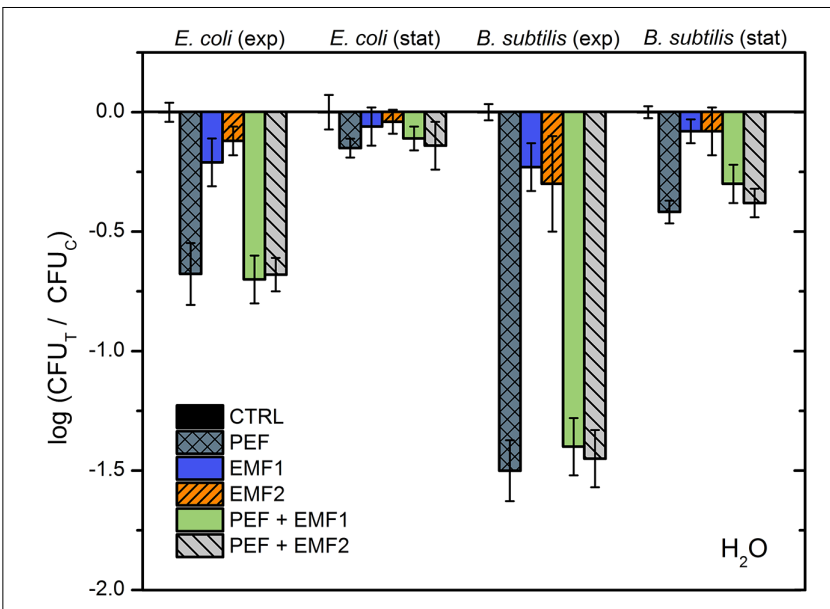

FIGURE 4 | Inactivation of $E$. coli and $B$. subtilis using different treatment protocols without NP, where PEF - $10 \mathrm{kV} \mathrm{cm}^{-1} \times 8 \times 100 \mu \mathrm{s}$; EMF1 3.3 T $\times 50,0.25 \mathrm{~Hz}$; EMF2 - $10 \mathrm{mT}, 100 \mathrm{kHz}, 2 \mathrm{~min}$. The number of residual culturable cells in the samples after the PEF treatment (CFU $)$ was compared with ones in the control samples without treatment $\left(\mathrm{CFU}_{\mathrm{C}}\right)$.

$10 \mathrm{kV} \mathrm{cm}^{-1}$ protocol was selected on purpose to prevent occurrence of saturated permeabilization and thus, potentially enable detection of synergistic response. The results for both bacteria are summarized in Figure 4.

As it can be seen in Figure 4, both the EMF protocols are barely influencing the survival of bacteria. Also, no additive effect with PEF was detected. Considering the acquired data, we have added NPs to include additional interactions of electromagnetic field. However, based on the inactivation efficiencies in PEF, we have narrowed the NPs to a pair of nisin-loaded (NisIONP-Ca) and nisin-free versions (IONP-Ca), which showed a stable antimicrobial response for both bacteria previously (Figures 2, 3). Then, the bacteria suspended with the selected NPs were treated in accordance with the methodology described above. The results for IONP-Ca and both bacteria are presented in Figure 5.

As it can be seen in Figure 5, the E. coli during exponential growth phase reacted to all of the applied external stimuli with both EMF protocols being similarly effective or even better than the $10 \mathrm{kV} \mathrm{cm}^{-1} \mathrm{PEF}$ (up to $1 \log$ reduction). The result was not so apparent for the B. subtilis, nevertheless both the EMF protocols showed an increase in antimicrobial efficiency if compared to NP-treatment only. Bacteria in stationary growth phase showed a weak response to the treatment, which is in agreement with the experimental data in PEF (Figures 2, 3); however, the synergistic response for the EMF2 + PEF protocol was still detectable for E. coli.

Results for the nisin-loaded version of NPs (Nis-IONP-Ca) are summarized in Figure 6. As it can be seen in Figure 6, a similar tendency is apparent for E. coli. A clear increase in inactivation efficiency is observed when the synergistic EMF + PEF protocols were applied. However, we have detected a significant reduction of treatment efficiency for B. subtilis when the NPs were used with EMF protocols. The effect was also apparent during combinational protocol (EMF2 + PEF). 


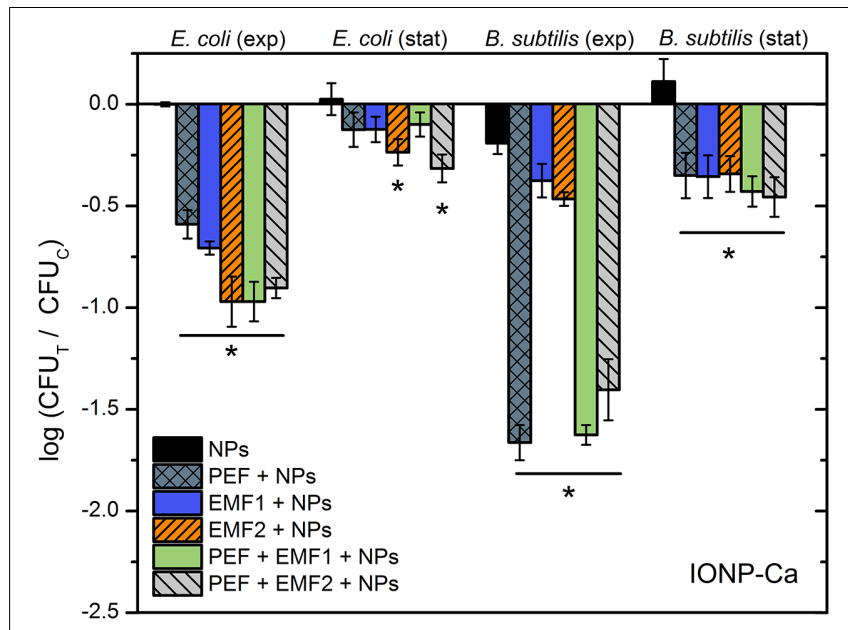

FIGURE 5 | Inactivation of $E$. coli and $B$. subtilis using different treatment protocols and nisin-unloaded iron oxide NP with $\mathrm{Ca}$ as a capping agent (IONP-Ca), where PEF - $10 \mathrm{kV} \mathrm{cm}^{-1} \times 8 \times 100 \mu \mathrm{s}$; EMF1 - 3.3 T $\times 50$, $0.25 \mathrm{~Hz}$; EMF2 - $10 \mathrm{mT}, 100 \mathrm{kHz}, 2 \mathrm{~min}$. The number of residual culturable cells in the samples after the PEF treatment $\left(\mathrm{CFU}_{\mathrm{T}}\right)$ was compared with ones in the control samples without treatment $\left(\mathrm{CFU} \mathrm{C}_{\mathrm{C}}\right)$. The asterisk ${ }^{*}$ ) represents statistically significant $(P<0.05)$ difference versus NPs only treatment.

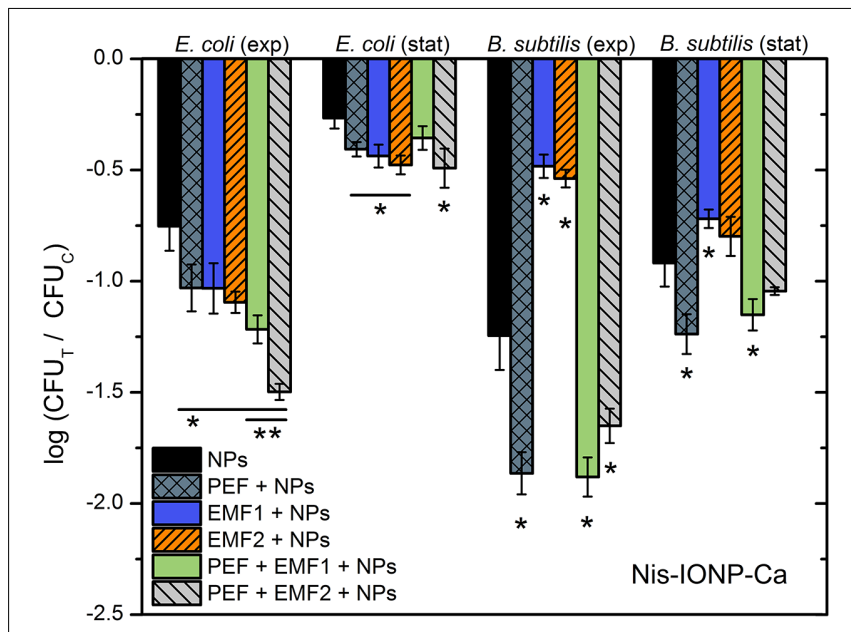

FIGURE 6 | Inactivation of $E$. coli and B. subtilis using different treatment protocols and nisin-loaded iron oxide NP with $\mathrm{Ca}$ as a capping agent (Nis-IONP-Ca), where PEF - $10 \mathrm{kV} \mathrm{cm}^{-1} \times 8 \times 100 \mu \mathrm{s}$; EMF1 - 3.3 T $\times 50$, $0.25 \mathrm{~Hz}$; EMF2 - $10 \mathrm{mT}, 100 \mathrm{kHz}, 2 \mathrm{~min}$. The number of residual culturable cells in the samples after the PEF treatment $\left(\mathrm{CFU}_{T}\right)$ was compared with ones in the control samples without treatment $\left(\mathrm{CFU}_{\mathrm{C}}\right)$. The asterisk $(*)$ represents statistically significant $(P<0.05)$ difference versus NPs only treatment. The asterisk $\left({ }^{* *}\right)$ represents statistically significant $(P<0.05)$ difference versus $\mathrm{PEF}+\mathrm{NPs}$ treatment

\section{DISCUSSION}

Various emerging technologies for food processing are introduced every year with a hope to present an economical, effective, and simple methodology for successful biopreservation of food without reduction of food quality. In this work, we have presented a novel method using targeted magnetic nisin nano-carriers, which are activated by combination of electric and high PEMF, allowing to overcome the initial nisin-resistance of E. coli. We have developed magnetic IONP and increased the antimicrobial efficiency of treatment using pulsed electric and magnetic fields. As a result, a proof of concept has been presented that the high pulsed magnetic fields increase the antimicrobial efficiency of nisin NPs similar to electroporation or magnetic hyperthermia methods, while a synergistic treatment is also possible.

We have shown that the electroporation can be effective by itself $\left(30 \mathrm{kV} \mathrm{cm}^{-1}\right)$ with or without the nisin NPs, which is in agreement with other PEF works (Žgalin et al., 2012; Flisar et al., 2014; Pataro et al., 2014). The effect could be attributed to the high permeabilization, which is induced due the increase of the transmembrane voltage in PEF (Zou et al., 2015). The cell wall of bacteria serves as an ultimate barrier against environment, however, electric field higher than $10 \mathrm{kV} \mathrm{cm}^{-1}$ is already sufficient to cause irreversible cell wall deterioration induced by both the mechanical and physical damage (Pillet et al., 2016). The plasma membrane protects Gram-negative bacteria from nisin incorporation, however, the application of PEF allows to permeabilize the bacteria and thus sensitize them to nisin treatment, which is in agreement with the currently known mechanisms of nisin resistance and PEF effects (Wouters et al., 2001; Vesković Moračanin et al., 2014; Zhou et al., 2014; Gharsallaoui et al., 2016). However, the combination of nisin NPs with PEMF was of upmost interest.

The high $\mathrm{d} B / \mathrm{d} t$ protocol proved to be as effective as the $10 \mathrm{kV} \mathrm{cm}^{-1}$ PEF procedure for the E. coli. Nevertheless, without the NPs both EMF protocols were ineffective. The explanation could lie within the mechanism behind the high pulsed magnetic field treatment. The high $\mathrm{d} B / \mathrm{d} t$ treatment is an emerging technique, however, the dominant idea is that the high magnetic field can result in induction of additional transmembrane potential in the cell and thus, stimulate permeabilization or affect the activity of ion channels (Towhidi et al., 2012; Kranjc et al., 2016; Zablotskii et al., 2016; Polyakova et al., 2017). The inability to affect the survival of bacteria solely by EMF is an expected result, due to relatively low (up to $0.2 \mathrm{kV} \mathrm{cm}^{-1}$ ) induced electric field if compared to the $10 \mathrm{kV} \mathrm{cm}^{-1}$ PEF treatment. The result is in agreement with the established electroporation theory, indicating that higher $\mathrm{d} B / \mathrm{d} t$ magnetic fields are required to permeabilize bacteria (Chen et al., 2006; Towhidi et al., 2012; Kranjc et al., 2016; Rems and Miklavčič, 2016; Novickij et al., 2017b). On contrary, magnetic NPs in combination with EMF induce significantly higher local field gradients, hyperthermia, and motion of both the cells and NPs, which all could attribute to increased inactivation efficiency (Deatsch and Evans, 2014; Salunkhe et al., 2014; Polyakova et al., 2017). The effect is apparent both with nisin-loaded and nisin-free NPs, which confirms the hypothesis.

Lastly, we have shown that both EMF protocols result in additive effects with PEF for inactivation of $E$. coli using nisin-loaded NPs, however, a significant reduction in treatment efficiency was observed for B. subtilis. B. subtilis is initially permeable to nisin, while high PEF exposure results in saturated 
permeabilization, which can explain the absence of additive effect with EMF. However, the decreased inactivation efficiency could be the cause of dielectrophoretic movement of cells and electromotive forces that are induced during EMF exposure, affecting passive diffusion and incorporation of nisin in the membrane. Currently, it is not possible to determine the exact mechanism and this phenomenon requires further investigation in future works.

We conclude that EMF is a versatile tool, which can be successfully used both separately and in combination with electroporation for sensitization of bacteria to antimicrobial peptides. However, further research is required in order to better understand the mechanisms of effect, determine the optimal parameters, and optimize the treatment efficiency. From the technological point of view, EMF methods are advantageous due to ease of incorporation in existing food

\section{REFERENCES}

Al-Holy, M. A., Al-Nabulsi, A., Osaili, T. M., Ayyash, M. M., and Shaker, R. R. (2012). Inactivation of Listeria innocua in brined white cheese by a combination of nisin and heat. Food Control 23, 48-53. doi: 10.1016/j.foodcont.2011.06.009

Assa, F., Jafarizadeh-Malmiri, H., Ajamein, H., Anarjan, N., Vaghari, H., Sayyar, Z., et al. (2016). A biotechnological perspective on the application of iron oxide nanoparticles. Nano Res. 9, 2203-2225. doi: 10.1007/s12274-016-1131-9

Atacan, K., Cakıroglu, B., and Ozacar, M. (2016). Improvement of the stability and activity of immobilized trypsin on modified Fe3O4 magnetic nanoparticles for hydrolysis of bovine serum albumin and its application in the bovine milk. Food Chem. 212, 460-468. doi: 10.1016/j.foodchem.2016.06.011

Blake, K. L., Randall, C. P., and O’Neill, A. J. (2011). In vitro studies indicate a high resistance potential for the lantibiotic nisin in Staphylococcus aureus and define a genetic basis for nisin resistance. Antimicrob. Agents Chemother. 55, 2362-2368. doi: 10.1128/AAC.01077-10

Bobinaite, R., Pataro, G., Lamanauskas, N., Satkauskas, S., Viskelis, P., and Ferrari, G. (2014). Application of pulsed electric field in the production of juice and extraction of bioactive compounds from blueberry fruits and their by-products. J. Food Sci. Technol. 52, 5898-5905. doi: 10.1007/s13197-0141668-0

Campion, A., Morrissey, R., Field, D., Cotter, P. D., Hill, C., and Ross, R. P. (2017). Use of enhanced nisin derivatives in combination with food-grade oils or citric acid to control Cronobacter sakazakii and Escherichia coli O157:H7. Food Microbiol. 65, 254-263. doi: 10.1016/j.fm.2017.01.020

Chandrasekaran, S., Ramanathan, S., and Basak, T. (2013). Microwave food processing-A review. Food Res. Int. 52, 243-261. doi: 10.1016/j.foodres.2013. 02.033

Chemat, F., Rombaut, N., Meullemiestre, A., Turk, M., Perino, S., Fabiano-Tixier, A. S., et al. (2017). Review of green food processing techniques. Preservation, transformation, and extraction. Innov. Food Sci. Emerg. Technol. 41, 357-377. doi: 10.1016/j.ifset.2017.04.016

Chen, C., Smye, S. W., Robinson, M. P., and Evans, J. A. (2006). Membrane electroporation theories: a review. Med. Biol. Eng. Comput. 44, 5-14. doi: 10.1007/s11517-005-0020-2

Cotter, P. D., Ross, R. P., and Hill, C. (2012). Bacteriocins - a viable alternative to antibiotics? Nat. Rev. Microbiol. 11, 95-105. doi: 10.1038/nrmicro2937

Deatsch, A. E., and Evans, B. A. (2014). Heating efficiency in magnetic nanoparticle hyperthermia. J. Magn. Magn. Mater. 354, 163-172. doi: 10.1016/j.jmmm.2013. 11.006

Dinali, R., Ebrahiminezhad, A., Manley-Harris, M., Ghasemi, Y., and Berenjian, A. (2017). Iron oxide nanoparticles in modern microbiology and biotechnology. Crit. Rev. Microbiol. 43, 493-507. doi: 10.1080/1040841X.2016.1267708

Flisar, K., Meglic, S. H., Morelj, J., Golob, J., and Miklavcic, D. (2014). Testing a prototype pulse generator for a continuous flow system and its use for E. coli inactivation and microalgae lipid extraction. Bioelectrochemistry 100, 44-51. doi: 10.1016/j.bioelechem.2014.03.008 processing systems, contactless treatment possibility, and thus absence of electrolysis and contamination, while we have shown a proof of concept that additive effects with PEF are also possible.

\section{AUTHOR CONTRIBUTIONS}

VN, ES, and JS conceived the experiments and methodology. RG, TK, and JS developed and produced the NPs, and performed the characterization. VN, RS, IV-M, and ES conducted the experiments, processed, and analyzed the results. $\mathrm{VN}$ and JN developed the pulsed magnetic and electric field systems. $\mathrm{VN}, \mathrm{ES}$, JS, and JN interpreted the results and wrote the manuscript. All authors reviewed and approved the final manuscript.

Gharsallaoui, A., Oulahal, N., Joly, C., and Degraeve, P. (2016). Nisin as a food preservative: part 1: physicochemical properties, antimicrobial activity, and main uses. Crit. Rev. Food Sci. Nutr. 56, 1262-1274. doi: 10.1080/10408398. 2013.763765

Golberg, A., Sack, M., Teissie, J., Pataro, G., Pliquett, U., Saulis, G., et al. (2016). Energy-efficient biomass processing with pulsed electric fields for bioeconomy and sustainable development. Biotechnol. Biofuels 9:94. doi: 10.1186/s13068016-0508-z

Gruskiene, R., Krivorotova, T., Staneviciene, R., Ratautas, D., Serviene, E., and Sereikaite, J. (2017). Preparation and characterization of nisin-loaded magnetic nanoparticles. J. Biotechnol. 256, S71-S71. doi: 10.1016/j.jbiotec.2017.06.1040

Haberl Meglic, S., Marolt, T., and Miklavcic, D. (2015). Protein extraction by means of electroporation from E. coli with preserved viability. J. Membr. Biol. 248, 893-901. doi: 10.1007/s00232-015-9824-7

Kardos, T. J., and Rabussay, D. P. (2012). Contactless magneto-permeabilization for intracellular plasmid DNA delivery in-vivo. Hum. Vaccines Immunother. 8, 1707-1713. doi: 10.4161/hv.21576

Keenan, D. F., Brunton, N. P., Gormley, T. R., Butler, F., Tiwari, B. K., and Patras, A. (2010). Effect of thermal and high hydrostatic pressure processing on antioxidant activity and colour of fruit smoothies. Innov. Food Sci. Emerg. Technol. 11, 551-556. doi: 10.1016/j.ifset.2010.07.003

Khan, S. I., Blumrosen, G., Vecchio, D., Golberg, A., Mccormack, M. C., Yarmush, M. L., et al. (2016). Eradication of multidrug-resistant Pseudomonas biofilm with pulsed electric fields. Biotechnol. Bioeng. 113, 643-650. doi: 10.1002/bit. 25818

Kotnik, T., Kramar, P., Pucihar, G., Miklavčič, D., and Tarek, M. (2012). Cell membrane electroporation - Part 1: the phenomenon. IEEE Electr. Insul. Mag. 28, 14-23. doi: 10.1109/MEI.2012.6268438

Kranjc, S., Kranjc, M., Scancar, J., Jelenc, J., Sersa, G., and Miklavcic, D. (2016). Electrochemotherapy by pulsed electromagnetic field treatment (PEMF) in mouse melanoma B16F10 in vivo. Radiol. Oncol. 50, 39-48. doi: 10.1515/raon2016-0014

Krivorotova, T., Cirkovas, A., Maciulyte, S., Staneviciene, R., Budriene, S., Serviene, E., et al. (2016). Nisin-loaded pectin nanoparticles for food preservation. Food Hydrocoll. 54, 49-56. doi: 10.1016/j.foodhyd.2015.09.015

Lammie, S. L., and Hughes, J. M. (2016). Antimicrobial resistance, food safety, and one health: the need for convergence. Annu. Rev. Food Sci. Technol. 7, 287-312. doi: 10.1146/annurev-food-041715-033251

Lee, J., and Kaletunç, G. (2010). Inactivation of Salmonella Enteritidis strains by combination of high hydrostatic pressure and nisin. Int. J. Food Microbiol. 140, 49-56. doi: 10.1016/j.ijfoodmicro.2010.02.010

Lee, J.-H., Jang, J., Choi, J., Moon, S. H., Noh, S., Kim, J., et al. (2011). Exchangecoupled magnetic nanoparticles for efficient heat induction. Nat. Nanotechnol. 6, 418-422. doi: 10.1038/nnano.2011.95

Lopes, N. A., and Brandelli, A. (2017). Nanostructures for delivery of natural antimicrobials in food. Crit. Rev. Food Sci. Nutr. 18, 1-11. doi: 10.1080/ 10408398.2017.1308915 
Mahnič-Kalamiza, S., Vorobiev, E., and Miklavčič, D. (2014). Electroporation in food processing and biorefinery. J. Membr. Biol. 247, 1279-1304. doi: 10.1007/ s00232-014-9737-x

Moore, T. L., Rodriguez-Lorenzo, L., Hirsch, V., Balog, S., Urban, D., Jud, C., et al. (2015). Nanoparticle colloidal stability in cell culture media and impact on cellular interactions. Chem. Soc. Rev. 44, 6287-6305. doi: 10.1039/C4CS0 0487F

Murashita, S., Kawamura, S., and Koseki, S. (2017). Effects of ohmic heating, including electric field intensity and frequency, on thermal inactivation of Bacillus subtilis spores. J. Food Prot. 80, 164-168. doi: 10.4315/0362-028X.JFP16-300

Niemirowicz, K., Durnaś, B., Tokajuk, G., Głuszek, K., Wilczewska, A. Z., Misztalewska, I., et al. (2016). Magnetic nanoparticles as a drug delivery system that enhance fungicidal activity of polyene antibiotics. Nanomed. Nanotechnol. Biol. Med. 12, 2395-2404. doi: 10.1016/j.nano.2016.07.006

Novickij, V., Dermol, J., Grainys, A., Kranjc, M., and Miklavčič, D. (2017a). Membrane permeabilization of mammalian cells using bursts of high magnetic field pulses. PeerJ 5:e3267. doi: 10.7717/peerj.3267

Novickij, V., Girkontaite, I., Zinkeviciene, A., Svediene, J., Lastauskiene, E., Paskevicius, A., et al. (2017b). Reversible permeabilization of cancer cells by high submicrosecond magnetic field. IEEE Trans. Magn. 53:9464, doi: 10.1109/ TMAG.2017.2719699

Novickij, V., Grainys, A., Lastauskiene, E., Kananavieiùte, R., Pamedytyte, D., Kalediene, L., et al. (2016a). Pulsed electromagnetic field assisted in vitro electroporation: a pilot study. Sci. Rep. 6:33537. doi: 10.1038/srep33537

Novickij, V., Lastauskiene, E., Svediene, J., Grainys, A., Staigvila, G., Paskevicius, A., et al. (2017c). Membrane permeabilization of pathogenic yeast in alternating sub-microsecond electromagnetic fields in combination with conventional electroporation. J. Membr. Biol. doi: 10.1007/s00232-017-9951-4 [Epub ahead of print].

Novickij, V., Stanevičienè, R., Grainys, A., Lukša, J., Badokas, K., Krivorotova, T., et al. (2016b). Electroporation-assisted inactivation of Escherichia coli using nisin-loaded pectin nanoparticles. Innov. Food Sci. Emerg. Technol. 38, 98-10. doi: 10.1016/j.ifset.2016.09.019

Pal, M. (2017). Pulsed electric field processing: an emerging technology for food preservation. J. Exp. Food Chem. 3, 2-3. doi: 10.4172/2472-0542.1000126

Pan, Y., Sun, D.-W., and Han, Z. (2017). Applications of electromagnetic fields for nonthermal inactivation of microorganisms in foods: an overview. Trends Food Sci. Technol. 64, 13-22. doi: 10.1016/j.tifs.2017.02.014

Pataro, G., De Lisi, M., Donsì, G., and Ferrari, G. (2014). Microbial inactivation of E. coli cells by a combined PEF-HPCD treatment in a continuous flow system. Innov. Food Sci. Emerg. Technol. 22, 102-109. doi: 10.1016/j.ifset.2013.12.009

Pillet, F., Formosa-Dague, C., Baaziz, H., Dague, E., and Rols, M.-P. (2016). Cell wall as a target for bacteria inactivation by pulsed electric fields. Sci. Rep. 6:19778. doi: 10.1038/srep19778

Pinilla, C. M. B., and Brandelli, A. (2016). Antimicrobial activity of nanoliposomes co-encapsulating nisin and garlic extract against Gram-positive and Gramnegative bacteria in milk. Innov. Food Sci. Emerg. Technol. 36, 287-293. doi: 10.1016/j.ifset.2016.07.017

Polyakova, T., Zablotskii, V., and Dejneka, A. (2017). Cell membrane pore formation and change in ion channel activity in high-gradient magnetic fields. IEEE Magn. Lett. 8:1507805. doi: 10.1109/LMAG.2017.2732361

Prombutara, P., Kulwatthanasal, Y., Supaka, N., Sramala, I., and Chareonpornwattana, S. (2012). Production of nisin-loaded solid lipid nanoparticles for sustained antimicrobial activity. Food Control 24, 184-190. doi: 10.1016/j.foodcont.2011.09.025

Rao, L., Wang, Y., Chen, F., and Liao, X. (2016). The synergistic effect of high pressure $\mathrm{CO} 2$ and nisin on inactivation of Bacillus subtilis spores in aqueous solutions. Front. Microbiol. 7:1507. doi: 10.3389/fmicb.2016.01507

Ravensdale, J., Wong, Z., O’Brien, F., and Gregg, K. (2016). Efficacy of antibacterial peptides against peptide-resistant mrsa is restored by permeabilization of bacteria membranes. Front. Microbiol. 7:1745. doi: 10.3389/fmicb.2016. 01745

Rawson, A., Patras, A., Tiwari, B. K., Noci, F., Koutchma, T., and Brunton, N. (2011). Effect of thermal and non thermal processing technologies on the bioactive content of exotic fruits and their products: review of recent advances. Food Res. Int. 44, 1875-1887. doi: 10.1016/j.foodres.2011.02.053
Rems, L., and Miklavčič, D. (2016). Tutorial: electroporation of cells in complex materials and tissue. J. Appl. Phys 119:201101. doi: 10.1063/1.4949264

Ristic, B. Z., Milenkovic, M. M., Dakic, I. R., Todorovic-Markovic, B. M., Milosavljevic, M. S., Budimir, M. D., et al. (2014). Photodynamic antibacterial effect of graphene quantum dots. Biomaterials 35, 4428-4435. doi: 10.1016/j. biomaterials.2014.02.014

Roca, I., Akova, M., Baquero, F., Carlet, J., Cavaleri, M., Coenen, S., et al. (2015). The global threat of antimicrobial resistance: Science for intervention. New Microbes New Infect. 6, 22-29. doi: 10.1016/j.nmni.2015.02.007

Salunkhe, A. B., Khot, V. M., and Pawar, S. H. (2014). Magnetic hyperthermia with magnetic nanoparticles: a status review. Curr. Top. Med. Chem. 14, 572-594. doi: 10.2174/1568026614666140118203550

Sreeja, V., Jayaprabha, K. N., and Joy, P. A. (2015). Water-dispersible ascorbicacid-coated magnetite nanoparticles for contrast enhancement in MRI. Appl. Nanosci. 5, 435-441. doi: 10.1007/s13204-014-0335-0

Towhidi, L., Firoozabadi, S. M. P., Mozdarani, H., and Miklavcic, D. (2012). Lucifer yellow uptake by $\mathrm{CHO}$ cells exposed to magnetic and electric pulses. Radiol. Oncol. 46, 119-125. doi: 10.2478/v10019-012-0014-2

Vallejo-Fernandez, G., Whear, O., Roca, A. G., Hussain, S., Timmis, J., Patel, V., et al. (2013). Mechanisms of hyperthermia in magnetic nanoparticles. J. Phys. D Appl. Phys. 46:312001. doi: 10.1088/0022-3727/46/31/312001

Vesković Moračanin, S. M., Dukić, D. A., and Memiši, N. R. (2014). Bacteriocins produced by lactic acid bacteria - A review. Acta Period. Technol. 45, 271-283. doi: 10.2298/APT1445271V

Wiedemann, I., Benz, R., and Sahl, H. G. (2004). Lipid II-mediated pore formation by the peptide antibiotic nisin: a black lipid membrane study. J. Bacteriol. 186, 3259-3261. doi: 10.1128/JB.186.10.3259-3261.2004

Wouters, P. C., Alvarez, I., and Raso, J. (2001). Critical factors determining inactivation kinetics by pulsed electric field food processing. Trends Food Sci. Technol. 12, 112-121. doi: 10.1016/S0924-2244(01)00067-X

Wu, W., Wu, Z., Yu, T., Jiang, C., and Kim, W. S. (2015). Recent progress on magnetic iron oxide nanoparticles: synthesis, surface functional strategies and biomedical applications. Sci. Technol. Adv. Mater. 16:023501. doi: 10.1088/ 1468-6996/16/2/023501

Zablotskii, V., Polyakova, T., Lunov, O., and Dejneka, A. (2016). How a highgradient magnetic field could affect cell life. Sci. Rep. 6:37407. doi: 10.1038/ srep37407

Žgalin, M. K., Hodžić, D., Reberšek, M., and Kandušer, M. (2012). Combination of microsecond and nanosecond pulsed electric field treatments for inactivation of Escherichia coli in water samples. J. Membr. Biol. 245, 643-650. doi: 10.1007/ s00232-012-9481-Z

Zhou, H., Fang, J., Tian, Y., and Lu, X. Y. (2014). Mechanisms of nisin resistance in Gram-positive bacteria. Ann. Microbiol. 64, 413-420. doi: 10.1007/s13213-0130679-9

Ziuzina, D., Han, L., Cullen, P. J., and Bourke, P. (2015). Cold plasma inactivation of internalised bacteria and biofilms for Salmonella enterica serovar Typhimurium, Listeria monocytogenes and Escherichia coli. Int. J. Food Microbiol. 210, 53-61. doi: 10.1016/j.ijfoodmicro.2015.05.019

Zohri, M., Shafiee Alavidjeh, M., Mirdamadi, S. S., Behmadi, H., Hossaini Nasr, S. M., Eshghi Gonbaki, S., et al. (2013). Nisin-loaded chitosan/alginate nanoparticles: a hopeful hybrid biopreservative. J. Food Saf. 33, 40-49. doi: $10.1111 /$ jfs. 12021

Zou, Y., Wang, C., Peng, R., Wang, L., and Hu, X. (2015). Theoretical analyses of cellular transmembrane voltage in suspensions induced by high-frequency fields. Bioelectrochemistry 102, 64-72. doi: 10.1016/j.bioelechem.2014.12.002

Conflict of Interest Statement: The authors declare that the research was conducted in the absence of any commercial or financial relationships that could be construed as a potential conflict of interest.

Copyright (c) 2018 Novickij, Stanevičienè, Vepštaité-Monstavičè, Gruškienè, Krivorotova, Sereikaite, Novickij and Serviene. This is an open-access article distributed under the terms of the Creative Commons Attribution License (CC BY). The use, distribution or reproduction in other forums is permitted, provided the original author(s) or licensor are credited and that the original publication in this journal is cited, in accordance with accepted academic practice. No use, distribution or reproduction is permitted which does not comply with these terms. 